It is becoming more generally recognised that the really "practical" man is the one who combines practical knowledge and experience with intelligent appreciation of underlying principles.

The aim of the book is to lay before sailors, in an easily comprehended manner, the principles on which the various mechanical devices employed by them are founded.

A large amount of useful information has therefore been gathered together in the small compass of this book, and rules and principles whose general application is explained in various text-books on practical and applied mechanics, are here specially adapted to the requirements of the sailor. To mention a few instances : we find explanations of the mechanical advantage gained by the various tackles and purchases; the construction of derricks and shears, and the weight they will support; the relative strengths of ropes; the breaking strains of spars; the floating power of spars and casks, and the weight which a raft, constructed of given materials, will bear; the effect of the wind on the sails in driving the ship ahead and in causing leeway; the effect of the water on the rudder; the extra strain thrown on slings when a ship is rolling, \&c.

The principles of the composition and resolution of forces, and of the mechanical powers are somewhat fully explained in the opening chapters, and the idea of applying the traverse table, so familiar to all sailors, to the solution of the problems, is an excellent one; but more explanation of some of the rules given later, which have to be taken for granted, could be desired, as it is very difficult to retain bare rules in the memory.

The size of the book no doubt imposed limits on the amount of space to be devoted to explanation, but it provides, nevertheless, an excellent book of reference; and though it may not be necessary to make some of the calculations referred to, it is always useful to know how things are worked, and on what principles, and that the principles are in accordance with well-known physical laws. "A sailor is so often thrown on his own resources, and the more exact his knowledge is of natural forces, the more readily can he avail himself of the forces at hand."

The book contains several valuable tables, and a useful collection of rules in mensuration.

\section{F. C. Stebing.}

Power Locomotion on the Highway. By Rhys Jenkins, M.I.Mech.E. Pp. 64. (London: William Cate, Ltd., I896.)

THE sub-title of this publication sufficiently expresses the character of the contents ; it is "a guide to the literature relating to traction engines and steam rollers and to the propulsion of common road carriages and velocipedes by steam and other mechanical power, with a brief historical sketch." The historical sketch is a concise statement of the lines along which progress in power locomotion on common roads has proceeded. Following it is a bibliography of works on mechanical carriages and traction engines, a catalogue of papers read before, or appearing in the Transactions of, scientific and technical societies, indexed under names of authors, a list of journals devoted to the mechanical carriage movement, and an index to articles on the subject in periodical literature up to the end of 1895 . The periodicals indexed include those of the United States, France, and Germany, as well as of Great Britain. The author has evidently been at considerable pains to prepare his descriptive index, and his efforts deserve encouragement. It would be an immense boon if indexes of the same description were available for other branches of technology. The reception afforded to this little book will show whether the demand is sufficient to justify the publication of others of a like kind.

$$
\text { NO. I 399, VOL. 54] }
$$

\section{LETTERS TO THE EDITOR.}

[The Editor does not hold himself responsible for opinions ex. pressed by his correspondents. Neither can he undertake to return, or to correspond with the writers of, rejected manuscripts intended for this or any other part of NATURE. No notice is taken of anonymous communications.]

\section{The Utility of Specific Characters.}

I REGRET very much that I did not correctly remember, when writing to NATURE a month ago, what my friend $\mathrm{Mr}$. Thiselton-Dyer had said at the Linnean Society's meeting. I suppose that in consequence I must not greatly complain that whilst telling us what he really did say, my friend has taken the opportunity to present a version of my views which is far from accurate. He has less excuse than I had in attempting to cite his remarks, since he has before him my printed letter of July 16. This fact also renders it easy to show wherein he is inaccurate.

I suppose that we are all agreed that it is in the highest degree interesting to know what Mr. Darwin himself thought and said on questions of the kind now under discussion. At the same time, we are none of us, I imagine, likely to attribute to Mr. Dyer a special knowledge either of Darwin's writings or of their interpretation which we do not share. Naturalists are, I believe, not prepared to accept any individual as the authoritative exponent of Mr. Darwin's teaching. Under these circumstances it is to me a matter for regret that a plain discussion of the question whether specific characters are invariably useful should be turned into a dispute as to whether the person who suggests some special application of Mr. Darwin's doctrines, or advances some subordinate hypothesis in relation to their application, can or can not be solemnly regarded as an Orthodox Darwinian. Mr. Dyer says that the Darwinian theory seems hardly to have a convinced supporter left except Mr. Wallace. He denounces my quotations from Mr. Darwin's own books as to correlation of variation as a "difficulty" brought up by me "against" the Darwinian theory; then, without more ado, assumes the rôle of apostle of the Darwinian theory (a part to which I cannot allow him any exclusive claim), and proceeds to tell us what "will" be found in the twenty-fifth chapter of Mr. Darwin's "Animals and Plants under Domestication," viz. that Darwin has said pretty much all that can (as yet) be said about the facts of correlation of variation. The attempt on Mr. Dyer's part to represent my citation of Mr. Darwin's own conclusions in regard to correlation of variation as unorthodox, is a little beside the mark. No one is ignorant that it "will" be found that in the chapter cited Mr. Darwin discusses "correlation"; not only that, but it has been so found long ago and repeatedly by many other readers besides Mr. Dyer. I expressly stated, both at the Linnean Society and in my letter printed in NaTURE on July I6, that I was quoting from Mr. Darwin both as to Wells and as to other instances.

Perhaps the most unsatisfactory feature in Mr. Dyer's claim to classify his friends as heterodox and orthodox in regard to Darwinism, is that it leads him to undertake to give away the Darwinian theory. "I frankly admit," he says, "that such a case a case of correlated variation such as that hypothetically stated by me] if completely established would give the utility of specific characters, and with it the Darwinian theory, a serious blow." I do not value this frank admission. If Mr. Dyer feels constrained to admit to some one that such a case would give a serious blow to the Darwinian theory, he must not come to me with his "admission" of a "point scored"; for I neither admit that any such blow is given, nor can I accept Mr. Dyer's goodnatured offer to act as representative of the Darwinian theory. All that my friend can represent in this matter is the Dyerian theory of Mr. Darwin's theory. Mr. Darwin never asserted in so many words that specific characters are invariably "useful," and in my judgment he did not hold that opinion. But whether he did or did not, that opinion can not, I think, be shown to be a necessary outcome of the theory of natural selection, provided that we take into consideration important ascertained properties of living matter. My impression is that Mr. Wallace m-whom Mr. Dyer has declared to be the only convinced supporter of the Darwinian theory now left-stated at the Linnean Society that he agreed with me as to "correlated variation" sometimes accounting for a specific character which accordingly could not be regarded as due to utility. Such also I gathered was the view of Mr. Meldola. Yet neither of these gentlemen regarded this conclusion as a serious blow to the Darwinian 